The Materials Research Society Foundation will leverage support to invest in projects of importance to the materials community, as defined by the materials community.

\title{
The Materials Research Society Foundation to benefit wide range of initiatives
}

www.mrs.org/foundation

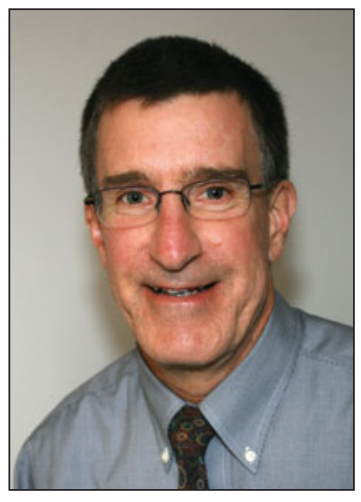

Bruce M. Clemens 2012 MRS President
At the beginning of my term as MRS President, I mentioned in this column that the hallmark of the Materials Research Society is its dedication to inform and engage the materials community. Just 10 months later, I'm even more firm in that conviction. From the June launch of Materials360 Online, our new website dedicated to materials science news and information, to taking our first steps toward a virtual meeting experience, MRS continues to lead the way with innovative and impactful programs that resonate with the materials community. And now I have the pleasure of announcing another transformative accomplishment - the Materials Research Society Foundation.

Just as MRS is unique in its egalitarian methodology, so too is the approach we are taking to launch our Foundation. For example, there is no independent mission for the Materials Research Society Foundation. Instead, the goal is to advance the MRS mission to "promote communication for the advancement of interdisciplinary materials research to improve the quality of life." The focus is on member engagement and funding to enrich, expand, and ensure MRS core programs in education, outreach, and peer recognition.

Unlike many foundations, there will be no capital campaign or endowment-building to fund a single, long-term society-determined project or program. Instead, this Foundation will benefit a wide range of innovative grassroots, member-driven initiatives - from student chapter proposals, to local or regional education/outreach projects, to those with the potential to impact the materials enterprise worldwide. The Materials Research Society Foundation will leverage corporate partner, institutional, and individual support to invest in projects of importance to the materials community, as defined by the materials community.

More information on the Foundation will be available in the coming months, including the Call for Proposals for grassroots projects, submission guidelines, and deadlines, so watch your email for details. And of course, the most up-to-date information will always be posted on the Foundation website. I encourage you to visit www.mrs.org/foundation to learn how you can make a difference or apply for project funding. The first project grants will be awarded at the 2013 MRS Spring Meeting in San Francisco.

The materials landscape is dotted with exciting and innovative grassroots projects, large and small, envisioned by our community and championed by our Society. As we launch the Materials Research Society Foundation, it is clear that we are now well-positioned to enrich that landscape with projects and partnerships that both serve the materials community and advance the global quality of life.

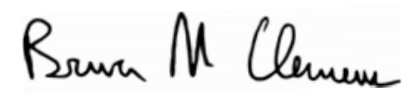

Bruce M. Clemens

2012 MRS President

The Materials Research Society Foundation operates as a program of The Materials Research Society. The official registration and financial information of the Materials Research Society Foundation may be obtained from the Pennsylvania Department of State by calling toll free, within Pennsylvania, 1.800.732.0999. Registration does not imply endorsement. 


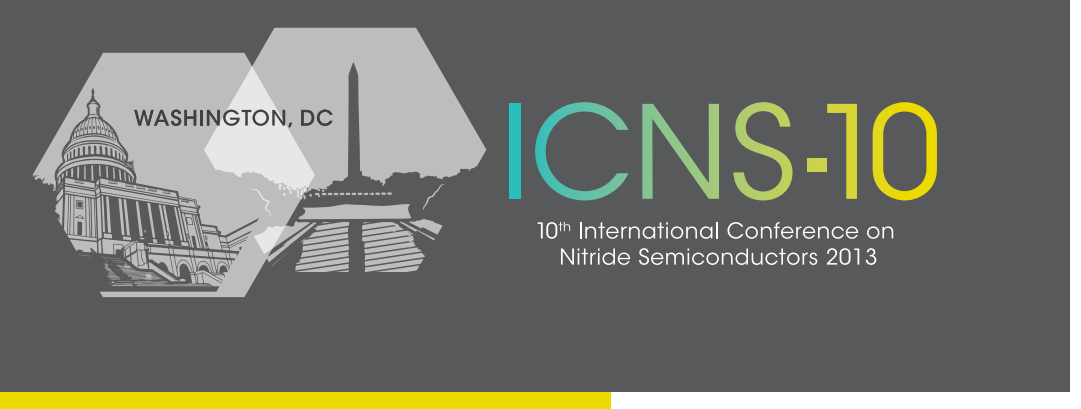

\section{CONFERENCE ORGANIZER:}

JAIME A. FREITAS, JR.

Naval Research Laboratory

CHRISTIAN M. WETZEL

Rensselaer Polytechnic Institute

\section{HONORARY CHAIR:}

ASIF KHAN

University of South Carolina

\section{IMPORTANT DATES:}

\section{ABSTRACT SUBMISSION OPENS}

Early February, 2013

ABSTRACT SUBMISSION ENDS

Mid April, 2013

PREREGISTRATION OPENS

Mid April, 2013

PREREGISTRATION ENDS

Early August, 2013

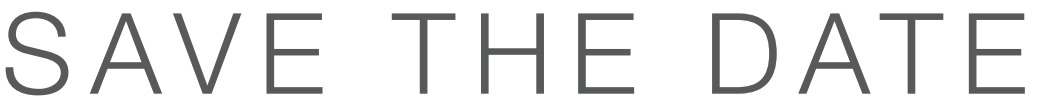

$10^{\text {th }}$ International Conference on Nitride Semiconductors | August 25-30, 2013 Gaylord National Hotel and Convention Center-Washington, D.C.

Join us for the 10th International Conference on Nitride Semiconductors 2013 (ICNS-10). Hosted in historic Washington, D.C., the conference will present high-impact scientific and technological advances in materials and devices based on group-III nitride semiconductors. The conference will feature plenary sessions, parallel topical sessions, poster sessions and an industrial exhibition. Mark your calendars today and plan to attend ICNS-10!

\section{Scientific Program}

The six-day conference will concentrate on the following topical categories:

- Bulk Crystal Growth

- Epitaxial Growth

- Optical and Electronic Properties

- Processing and Fabrication

- Defect Characterization and Engineering

- Structural Analysis

- Theory and Simulation

- Nanostructures

- Light Emitting Devices

- Electron Transport Devices

- Photovoltaics and Energy Harvesting

- New Materials and New Device Concepts

\section{Conference Venue}

ICNS-10 will be held at the beautiful National Harbor, located on the banks of the Potomac River. This unique, ever expanding complex, offers something interesting and different for everyone in the family. Featuring numerous shopping, dining and entertainment venues, the waterfront community brings the finest options from land or water. Just minutes from the harbor, find one of the world's cultural, government and historic epicenters-Washington, D.C. The architecture, monuments, museums and cultural diversity add up to one ideal conference and vacation destination.

For the most up-to-date information on ICNS-10, visit www.ICNS10.org.
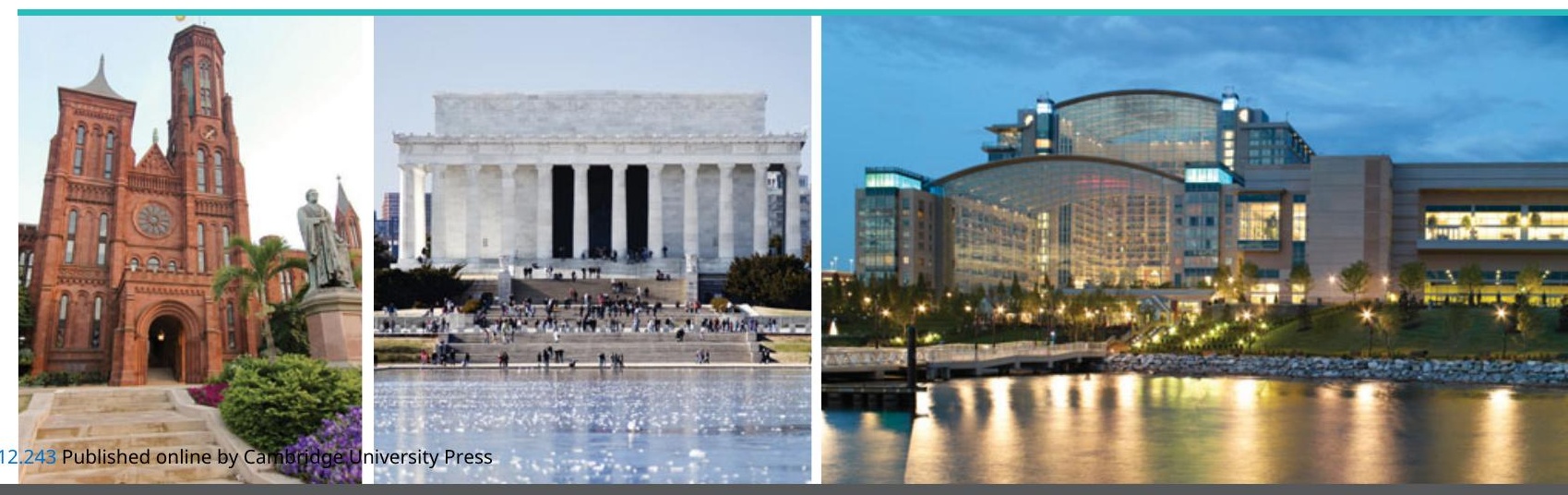